\title{
Cancer testis antigen and immunotherapy
}

\author{
This article was published in the following Dove Press journal: \\ ImmunoTargets and Therapy \\ 17 April 2013 \\ Number of times this article has been viewed
}

\section{Deepa Kolaseri Krishnadas \\ Fanqi Bai \\ Kenneth G Lucas \\ Department of Pediatrics, Division of Hematology/Oncology, University of Louisville, KY, USA}

\begin{abstract}
The identification of cancer testis (CT) antigens has been an important advance in determining potential targets for cancer immunotherapy. Multiple previous studies have shown that CT antigen vaccines, using both peptides and dendritic cell vaccines, can elicit clinical and immunologic responses in several different tumors. This review details the expression of melanoma antigen family A, 1 (MAGE-A1), melanoma antigen family A, 3 (MAGE-A3), and New York esophageal squamous cell carcinoma-1 (NY-ESO-1) in various malignancies, and presents our current understanding of CT antigen based immunotherapy.

Keywords: cancer testis antigens, immunotherapy, vaccine
\end{abstract}

\section{Introduction}

The past two decades have witnessed major strides in the treatment of several pediatric and adult cancers, particularly with the use of multiagent chemotherapy, radiation therapy, and recently, monoclonal antibodies. Nevertheless, a subset of these patients will develop resistance to these modalities, leaving few treatment options with curative potential. In addition, patients with high risk metastatic disease continue to have dismal treatment outcomes, despite these advances. Therefore, for patients with relapsed, therapy refractory disease and tumors at high risk for recurrence, new treatment strategies are desperately needed.

Over the past two decades numerous groups have investigated immune-based therapies for patients with relapsed cancer. The success in using adoptive cellular immunotherapy to fight viral infections following allogeneic stem cell transplantation has encouraged some groups to focus their efforts on the infusion of cancer antigen specific, or otherwise activated, T lymphocytes. ${ }^{1,2}$ There is a long history of clinical investigation with cancer vaccines for a variety of malignant solid tumors. The recognition that dendritic cells (DC) play a key role in antigen presentation led to several groups using DC pulsed with cancer relevant antigens, while other groups have used whole tumor antigens or human leukocyte antigen (HLA) restricted epitopes. ${ }^{3,4}$ Several different antigens have been targeted in these strategies, most notably the cancer testis (CT) antigens. These tumor proteins are of interest since they are expressed on several malignant solid tumors, as well as some leukemias, and have a restricted pattern of expression, thereby limiting the possibility of an immune response directed against normal host tissues. These antigens can also be epigenetically upregulated on tumors following exposure to demethylating chemotherapy agents, potentially making tumors more susceptible to killing by antigen-specific $\mathrm{T}$ cells that have been stimulated 
following a $\mathrm{CT}$ antigen vaccine. In this review we will summarize past studies which target these antigens and future directions in CT antigen-based immunotherapy.

\section{Cancer immunotherapy}

An improved understanding of cellular immunology has helped to facilitate the rational design of cancer immunotherapy strategies. While conventional therapy such as chemotherapy and radiation are useful for the majority of patients, the use of these modalities alone may be insufficient for patients with relapsed cancer or for those who initially present with advanced disease. Chemotherapy often has limited efficacy in patients with relapsed disease, for whom intensification of conventional therapy to overcome drug resistance can lead to significant morbidity.

Immunotherapy can specifically target, or in general, modulate cellular immune responses against cancer proteins and has the potential to provide long-lasting responses. Adoptive transfer of autologous in vitro generated and expanded effector $\mathrm{T}$ cells is one such effective method. Initial studies in adoptive immunotherapy were performed in the allogeneic stem cell transplant setting to fight serious, potentially life-threatening viral infections, such as cytomegalovirus and Epstein-Barr virus. While adoptive immunotherapy has been largely successful against several viral infections ${ }^{5-7}$ this approach has had limited success against cancer. The precursor frequency of cancer antigenspecific cells is very low, and the expansion of these cells requires multiple stimulations. In addition, the low avidity of expanded $\mathrm{T}$ cells against cancer antigens and the short life span of adoptively transferred effector $T$ cells are practical limitations of adoptive immunotherapy. Several strategies have been developed to overcome these challenges, such as the use of chimeric antigen receptors, ${ }^{8} \mathrm{~T}$ cells genetically engineered to express $\mathrm{T}$ cell receptors (TCRs) with high affinity and specificity, ${ }^{9,10}$ and bispecific antibodies to promote $\mathrm{T}$ cell recognition of tumors. ${ }^{11}$

Several immune evasion mechanisms pose major obstacles for the practical application of immunotherapy against cancer. Tumor cells can evade the immune system by (a) downregulating the expression of major histocompatibility complex (MHC) class I and class II molecules that are required for antigen presentation to T cells; (b) downregulating costimulatory molecules, such as CD80 and CD86, which are required for optimal activation of T cells; (c) upregulating coinhibitory molecules, such as cytotoxic T-lymphocyte antigen 4 (CTLA-4) ligands and programmed cell death ligand
1 (PDL-1), on tumor cells; ${ }^{10}$ and (d) recruiting regulatory $\mathrm{T}$ cells (Tregs) that produce immunosuppressive cytokines at the tumor site. For example, high expression of CTLA-4 has been correlated with increased $\mathrm{T}$ cell dysfunction in melanoma patients. ${ }^{12}$ CTLA-4 and programmed cell death 1 (PD-1) are expressed on activated $\mathrm{T}$ cells and contribute to $\mathrm{T}$ cell exhaustion. The upregulation and ligation of CTLA-4/PD-1 (on T cells) with CTLA-4 ligands and PDL-1 (on tumor cells) dampens effector $\mathrm{T}$ cell activation and negatively attenuates adaptive immune responses. ${ }^{13}$ Researchers have developed strategies to overcome the immunosuppressive tumor microenvironment by blocking the inhibitory pathways. ${ }^{14}$ Therefore antibodies blocking CTLA-4 or PD- 1 on T cells can prevent the inhibitory signals typically transmitted through these receptors and prevent effector cells from entering into the exhaustion phase, thereby extending the life and function of activated $\mathrm{T}$ cells. It seems logical to combine genetically targeted therapies/adoptive immunotherapy with negative regulatory blockade to minimize the chances of tumor resistance and escape. Accordingly, Treg depletion followed by PD-1/PDL-1 blockade has shown some efficacy in the treatment of acute myeloid leukemia (AML). ${ }^{15}$ In a Phase I clinical trial of antibody-mediated PD-1 blockade, an objective response (complete response [CR] or partial response [PR]) was observed in those with non-small-cell lung cancer ([NSCLC] 18\%), melanoma (28\%), and renal cell cancer ([RCC] 27\%). ${ }^{16}$ A similar Phase I trial using antibody-mediated blockade of PDL-1 induced durable tumor regression and prolonged stabilization of disease in patients with advanced cancers. ${ }^{17} \mathrm{~A}$ study has evaluated the contributions of CTLA-4 blockade on effector T cells and Treg populations in a mouse model of melanoma. ${ }^{18}$ It revealed that CTLA-4 blockade on effector cells significantly improves tumor protection while blockade of Tregs completely fails to enhance antitumor responses, and a concomitant blockade of both effector and Tregs leads to maximal antitumor activity. CTLA-4 blockade with ipilimumab (an anti-CTLA-4 antibody) has resulted in some clinical responses in patients with melanoma, ovarian cancer, prostate cancer, and RCC. ${ }^{19}$ A Phase III trial showed that ipilimumab, when given with or without a glycoprotein (gp)100 peptide vaccine, improved the overall survival to 10 months when compared to 6.4 months with gp100 alone in patients with metastatic melanoma. ${ }^{20}$ Several Phase II studies suggest that ipilimumab is effective in patients with melanoma and brain metastases. ${ }^{21,22}$ In a Phase II trial of ipilimumab plus fotemustine in 86 patients with advanced melanoma, of whom 20 patients had asymptomatic brain metastases at baseline. 40 of $86(46.5 \%)$ patients in 
the study population achieved disease control similar to 10 of 20 patients $(50 \%)$ with brain metastases. ${ }^{23}$ Furthermore, ipilimumab when combined with decarbazine improved the overall survival to $47 \%$ when compared to decarbazine alone $(36 \%){ }^{24}$ These results suggest that blocking the immune checkpoints can improve overall survival in cancer patients.

\section{Cancer vaccines and immunotherapy}

The success of a cancer vaccine is dependent on the ability of a patient to mount a primary or memory immune response against cancer antigens used in the vaccine. Thus far, the majority of cancer vaccine studies have focused on patients with relapsed or therapy refractory disease, but there is a growing interest on the potential to use this approach to prevent relapse in patients who are at high risk for recurrence. Three main types of cancer vaccines that have been used in previous studies, including cellular vaccines, largely consist of DCs pulsed with cancer relevant antigens or tumor cell lysates, protein- or peptidebased vaccines, and vector-based vaccines where plasmid DNA and viral/bacterial/yeast vectors are used to deliver tumor-specific antigens. ${ }^{25}$ Potential problems with using whole cell lysates, peptides, or plasmid DNA approaches include the immunogenicity of the vaccine, the majority of cancer reactive $\mathrm{T}$ cells exist in low numbers and are difficult to expand, and that most tumors have developed multiple means to evade the immune system. Adjuvants can be used to enhance vaccine immunogenicity and thereby increase the likelihood of eliciting a $\mathrm{T}$ cell response. Granulocyte-macrophage colony-stimulating factor (GM-CSF) has been used as an adjuvant in several types of tumors including melanoma, colorectal carcinoma, RCC, and lymphoma. For example, an idiotypic protein vaccine together with GM-CSF resulted in complete molecular remission (by polymerase chain reaction [PCR]) in 8 of 11 lymphoma patients and tumor-specific cytotoxic CD4+ and CD8+ cells were found in $95 \%$ of the patients. ${ }^{26}$ DCs play a central role in initiating antitumor responses by activating innate and adaptive immune cells. Different DC subsets express distinct toll-like receptors (TLRs), such as TLRs 1 to 8, and upon stimulation, upregulate costimulatory molecules, pro-inflammatory cytokines, and chemokines which can assist in priming tumor-specific $\mathrm{T}$ cells. Therefore, different types of TLR agonists have been used as adjuvants along with DC-based vaccines in treating glioblastoma, breast cancer, melanoma, $\mathrm{RCC}$, and leukemia. ${ }^{27} \mathrm{~A}$ list of clinical trials using DC as therapeutic vaccines has been detailed in a comprehensive review of cancer immunotherapy with these antigen presenting cells. ${ }^{28}$

\section{Cancer testis antigens}

An ideal tumor antigen for immunotherapy should be (a) expressed specifically on tumor cells and not on healthy cells, (b) stably and homogenously expressed on all/ majority of tumor cells, (c) vital for the existence of cancer cells, and (d) targeted by tumor antigen-specific cytotoxic T lymphocytes. ${ }^{29}$ Identification of such tumor antigens would enhance the success of cancer vaccines.

CT antigens are tumor proteins with a restricted pattern of expression, generally limited to germ cell and trophoblast tissue, but are also expressed in various human cancers. Their stable and specific expression on tumor cells and lack of expression on normal tissues make them an attractive target for cancer immunotherapy. Based on the frequency of CT antigen expression, Chen et $\mathrm{al}^{30}$ and Caballero and $\mathrm{Chen}^{31}$ classified certain types of cancers including melanoma, ovarian cancer, lung cancer, and bladder cancer as "CT-rich" tumors; RCC, colorectal cancer, and lymphoma/leukemia as "CT-poor" tumors; and breast cancer, bladder cancer, and prostate cancer as "CT-intermediate" tumors. CT antigens are divided into two groups: CT-X (encoded on X chromosome) and non-X CT antigens. An excellent review by Simpson et al summarizes the characteristics and functions of these two types of CT antigens. ${ }^{29}$ Until 2004, there were around 40 CT antigens identified, ${ }^{33}$ but by 2012 , the number of CT antigens identified had increased to $110 .{ }^{32}$ Our review will focus mainly on melanoma antigen family (MAGE)-A1, MAGE-A3, and New York esophageal squamous cell carcinoma (NY-ESO-1), three of the initially identified and most widely studied CT antigens in melanoma.

MAGE-A1 and MAGE-A3 are members of the MAGE gene family that are expressed on male germ line cells and placenta, as well as in melanoma, bladder cancer, breast cancer, prostate cancer, and NSCLC. ${ }^{33}$ NY-ESO-1 is another $\mathrm{CT}$ antigen found on several tumors, including in ovarian cancer, lung cancer, melanoma, as well as some sarcomas and neuroblastomas. ${ }^{34}$ Expression rates of MAGE-A1 and MAGE-A3 were $53.7 \%$ and $36.6 \%$, respectively, in ovarian cancer. ${ }^{35}$ Several MAGE-A1 peptides restricted to individual HLA alleles have been reported in healthy donors. ${ }^{36-38}$ The frequency of expression of MAGE-A1 and NY-ESO-1 in bladder cancer versus liver cancer was $22 \%$ and $80 \%$ versus $80 \%$ and $29 \%$, respectively. ${ }^{33}$ In pharyngeal tumors, MAGE-A and NY-ESO-1 were detectable in 70\% and 33.3\% of tumors, respectively. ${ }^{39}$ In NSCLC patients, the expression of NY-ESO-1 was only $8.3 \%,{ }^{40}$ while its expression in synovial sarcoma was $80 \%,{ }^{41}$ and its expression was $100 \%$ in myxoid/round cell liposarcoma patients. ${ }^{42}$ Screening neuroblastoma cell lines for these antigens by reverse 
transcriptase-PCR (RT-PCR) has revealed that 44\% are positive for MAGE-A1, 21\% for MAGE-A3, and 30\%$82 \%$ for NY-ESO-1, and immunohistochemical analysis has shown a good correlation between gene and protein expression. ${ }^{43}$ In addition, in neuroblastoma, a higher level of NY-ESO-1 expression has been reported in patients with later stage disease. ${ }^{44}$ The frequency of MAGE-A1 expression increased from $20 \%$ (in primary tumors) to $51 \%$ with advanced disease (in distant metastases), while NY-ESO-1 expression remained at $45 \%$, regardless of stage of disease in melanoma patients. ${ }^{45}$ In malignant gammopathies, the expression pattern of MAGE-A1, MAGE-A3, and NY-ESO-1 was heterogeneous, and the expression of these antigens was greater in patients with stage III extramedullary plasmacytoma or high risk myeloma relative to low risk disease groups. ${ }^{46}$ This indicates that levels of expression of CT antigens vary depending upon the type of cancer and the stage of a patient's disease, with many tumors having increased expression of CT antigens upon progression/relapse. ${ }^{45-47}$

The expression of CT antigens on tumors has been correlated with the presence of CT antigen-specific $B$ and $T$ cell responses. Studies in adult patients have demonstrated that MAGE-A1 and MAGE-A3 specific T cells are present and can be augmented with a vaccine, or by stimulation of these $\mathrm{T}$ cells in culture. ${ }^{48-51}$ There is also a correlation between the detection of MAGE-A3 specific $\mathrm{CD}^{+} \mathrm{T}$ cells and regression of tumors in melanoma patients. ${ }^{52}$ MAGE-specific $\mathrm{CD}^{+} \mathrm{T}$ cell responses have been reported in AML patients. ${ }^{53}$ In adult $\mathrm{T}$ cell leukemia/ lymphoma cells, NY-ESO-1 and MAGE-A3 were expressed in $61.4 \%$ and $31.6 \%$ of cells, respectively. This study detected NY-ESO-1 specific antibodies in $11.6 \%$, and NY-ESO-1 specific $\mathrm{CD}^{+} \mathrm{T}$ cell responses in $55.6 \%$, of adult $\mathrm{T}$ cell leukemia/lymphoma patients. ${ }^{54}$ Another study demonstrated $\mathrm{CD}^{+} \mathrm{T}$ cell responses in 10 of 11 patients with NY-ESO-1 positive melanoma who had NY-ESO-1 antibodies, but not in patients with NY-ESO-1 negative tumors or those lacking antibodies. ${ }^{55,56}$ There has also been a report on the detection of interferon- $\gamma($ IFN- $\gamma$ ) producing NY-ESO-1 specific T cells in neuroblastoma patients. ${ }^{45}$ These studies indicate that MAGE-A1, MAGE-A3, and NY-ESO-1 are immunogenic and capable of eliciting $\mathrm{T}$ and $\mathrm{B}$ cell responses.

Clinical trials have been reported using DC-based vaccines, whole protein vaccines, or HLA restricted epitopes for MAGE-A1 and MAGE-A3 positive malignancies. Chianese-Bullock et al gave vaccines consisting of
MAGE-A1, MAGE-A10, and gp100 peptides with GM-CSF and incomplete Freund's adjuvant to patients with stage IIB to IV melanoma. ${ }^{49}$ There were increases in MAGE-A1 specific IFN- $\gamma$ production postvaccination, and cytotoxic $\mathrm{T}$ lymphocyte (CTL) from these patients lysed tumor cells expressing MAGE-A1. MacKensen et al reported on the results of a MAGE-A1 and MAGE-A3 peptide loaded DC vaccine in 14 melanoma patients. ${ }^{57}$ Clinical and immunologic responses were seen in two patients, and increased melanoma peptide specific immune responses were seen in four patients. ${ }^{57}$ Thurner et al reported the use of MAGE-A3 peptide pulsed mature DC at doses of $3 \times 10^{6}$ DC per vaccine, given at 14 day intervals. ${ }^{51}$ Significant expansion of MAGE-A3 specific $\mathrm{CD}^{+}$cytotoxic $\mathrm{T}$ cells was induced in 8 of 11 patients, with regression of individual metastases in 6 of 11 patients. The ongoing clinical trials with CT antigens, MAGE-A1, MAGE-A3, and NY-ESO-1 are presented in Table 1.

The majority of clinical trials with NY-ESO-1 tumor vaccines have used either individual HLA restricted epitopes or whole protein, with or without adjuvants. Most of these studies have demonstrated enhancement of $\mathrm{T}$ and $\mathrm{B}$ cell responses to this antigen postvaccination. Some of the initial clinical trials with NY-ESO-1 peptide vaccines used HLA-A2 restricted peptides, and demonstrated that $\mathrm{CD}^{+}$ $\mathrm{T}$ cell responses can be expanded postvaccination. ${ }^{56,58,59}$ Bender et al used an HLA-A2 restricted NY-ESO-1 peptide for vaccination, and reported that three of nine seronegative patients developed $\mathrm{CD} 8^{+} \mathrm{T}$ cell responses. ${ }^{60}$ One study used full length NY-ESO-1 protein with the ISCOMATRIX ${ }^{\mathrm{TM}}$ adjuvant in 46 patients with fully resected, NY-ESO-1 positive tumors. ${ }^{61}$ These investigators found high titer antibody responses, as well as $\mathrm{CD}^{+}$and $\mathrm{CD}^{+} \mathrm{T}$ cell responses, against a wide range of NY-ESO-1 epitopes postvaccination. There was improved survival, with only two of 19 relapses in the group receiving adjuvant and protein, in comparison with nine of 16 relapses in the group receiving protein alone. Upon further evaluation, persisting anti-NY-ESO-1 immunity was detected in ten of 14 recipients who had previously received vaccine with ISCOMATRIX ${ }^{\mathrm{TM}}$ adjuvant, while immunity only persisted in three of 14 recipients who received vaccine alone. ${ }^{62}$

\section{Combination therapy}

A major focus of research during the past two decades has been to identify methods to overcome the mechanisms used by tumors to evade the immune system. Different approaches including conventional therapy, molecular-targeted 
Table I Ongoing clinical trials with the cancer testis antigens MAGE-AI, MAGE-A3, and NY-ESO-I

\begin{tabular}{|c|c|c|c|}
\hline Tumor type & $\begin{array}{l}\text { Cancer testis (CT) } \\
\text { antigen }\end{array}$ & Combination & $\begin{array}{l}\text { ClinicalTrials. } \\
\text { gov identifier }\end{array}$ \\
\hline $\begin{array}{l}\text { Neuroblastoma } \\
\text { and sarcoma }\end{array}$ & $\begin{array}{l}\text { MAGE-AI, } \\
\text { MAGE-A3, NY-ESO-I }\end{array}$ & $\begin{array}{l}\text { CT antigen specific dendritic cell vaccine preceded by decitabine } \\
\text { as a demethylating chemotherapy }\end{array}$ & $\begin{array}{l}\text { NCT0I } 24 I I 62 \\
(\mathrm{R})\end{array}$ \\
\hline Myeloma & MAGE-A3 & Combination of MAGE-A3 vaccine plus activated $\mathrm{T}$ cells & $\begin{array}{l}\text { NCTOI } 245673 \\
\text { (R) }\end{array}$ \\
\hline Myeloma & MAGE-A3, NY-ESOI & $\begin{array}{l}\mathrm{CT} \text { antigen peptides in combination with DTPACE chemotherapy } \\
\text { and auto transplantation }\end{array}$ & $\begin{array}{l}\text { NCT00090493 } \\
\text { (R) }\end{array}$ \\
\hline Melanoma & $\begin{array}{l}\text { NY-ESO-Ib, } \\
\text { MAGE-AIO }\end{array}$ & $\begin{array}{l}\text { Vaccine with NY-ESO-Ib and MAGE-AIO and montanide, CPG } \\
\text { and low dose IL-2 }\end{array}$ & $\begin{array}{l}\text { NCTOOII } 2242 \\
\text { (A) }\end{array}$ \\
\hline Melanoma & NY-ESO-I & TLR3 agonist adjuvant and NY-ESO-I vaccination & $\begin{array}{l}\text { NCTOI07974I } \\
\text { (A) }\end{array}$ \\
\hline Melanoma & NY-ESO-I & $\begin{array}{l}\text { GSK224I658A antigen-specific cancer immunotherapeutic for } \\
\text { NY-ESO-I positive melanoma }\end{array}$ & $\begin{array}{l}\text { NCTOI } 213472 \\
(\mathrm{R})\end{array}$ \\
\hline $\begin{array}{l}\text { NY-ESO-I } \\
\text { expressing } \\
\text { solid tumors }\end{array}$ & NY-ESO-I & $\begin{array}{l}\text { DEC-205-NY-ESO-I fusion protein vaccine with or without } \\
\text { sirolimus (immunosuppressant drug) for NY-ESO-I positive tumors }\end{array}$ & $\begin{array}{l}\text { NCTOI522820 } \\
(\mathrm{R})\end{array}$ \\
\hline $\begin{array}{l}\text { NY-ESO-I positive } \\
\text { cancer }\end{array}$ & NY-ESO-I & $\begin{array}{l}\text { CDX-I40I cancer vaccine in combination with an immune stimulant } \\
\text { (resiquimod and/or Hiltonol }{ }^{\circledR} \text { [Poly-ICLC]) for NY-ESO-I positive cancer }\end{array}$ & $\begin{array}{l}\text { NCT0094896I } \\
\text { (A) }\end{array}$ \\
\hline Melanoma & NY-ESO-I & $\begin{array}{l}\text { Chemotherapy (cyclophosphamide or fludarabine phosphate) } \\
\text { followed by an infusion of anti-NY-ESO-I TCR gene engineered } \\
\text { lymphocytes for NY-ESO-I positive melanoma }\end{array}$ & $\begin{array}{l}\text { NCT00670748 } \\
(\mathrm{R})\end{array}$ \\
\hline Melanoma & $\begin{array}{l}\text { NY-ESO-I, } \\
\text { MAGE-A3 }\end{array}$ & Vaccination with tumor antigenic peptides and montanide & $\begin{array}{l}\text { NCT0I } 308294 \\
(\mathrm{R})\end{array}$ \\
\hline $\begin{array}{l}\text { Small cell lung } \\
\text { cancer }\end{array}$ & $\begin{array}{l}\text { NY-ESO-I, } \\
\text { MAGE-A3, MAGE-AI }\end{array}$ & $\begin{array}{l}\text { Chemotherapy (platinum) with immunotherapy (CT antigen pulsed } \\
\text { dendritic cell) }\end{array}$ & $\begin{array}{l}\text { NCTOII59288 } \\
(\mathrm{R})\end{array}$ \\
\hline Melanoma & MAGE-A3 & $\begin{array}{l}\text { Combination immunotherapy (MAGE-A3 immunizations with } \\
\text { Hiltono }{ }^{\otimes}[\text { Poly-ICLC }] \text { plus transfer of vaccine-primed autologous } \\
\text { T cells) after autologous stem cell transplantation (ASCT) }\end{array}$ & $\begin{array}{l}\text { NCTOI } 245673 \\
(\mathrm{R})\end{array}$ \\
\hline $\begin{array}{l}\text { Non-small-cell } \\
\text { lung cancer }\end{array}$ & MAGE-A3 & $\begin{array}{l}\text { Chemotherapy (cisplatin and vinorelbine) with cancer } \\
\text { immunotherapeutic GSK I572932A as adjuvant therapy } \\
\text { for MAGE-A3 positive non-small-cell lung cancer }\end{array}$ & $\begin{array}{l}\text { NCT00455572 } \\
(\mathrm{R})\end{array}$ \\
\hline Melanoma & MAGE-A3 & $\begin{array}{l}\text { Vaccination with melanoma tumor associated antigen (MART, } \\
\text { MAGE-3, tyrosinase, and gP I00) RNA loaded dendritic cells } \\
\text { derived from untreated monocytes }\end{array}$ & $\begin{array}{l}\text { NCT00672542 } \\
\text { (A) }\end{array}$ \\
\hline Melanoma & MAGE-A3 & $\begin{array}{l}\text { Recombinant MAGE-A3 protein combined with ASI } 5 \text { immunological } \\
\text { adjuvant system (recMAGE-A3 + ASI5) as an antigen-specific cancer } \\
\text { immunotherapeutic for MAGE-A3 positive tumor }\end{array}$ & $\begin{array}{l}\text { NCTOI425749 } \\
\text { (R) }\end{array}$ \\
\hline Melanoma & MAGE-A3 & Peptide vaccine (MAGE-3AI) plus galectin-3 inhibitor (GM-CT-I) & $\begin{array}{l}\text { NCT0I7238I3 } \\
\text { (R) }\end{array}$ \\
\hline Synovial carcinoma & NY-ESO-I & $\begin{array}{l}\text { Genetically engineered NY-ESO-I specific (c259) T cells with } \\
\text { chemotherapy (doxorubicin) }\end{array}$ & $\begin{array}{l}\text { NCTOI } 343043 \\
(\mathrm{R})\end{array}$ \\
\hline $\begin{array}{l}\text { NY-ESO-I positive } \\
\text { metastatic tumor }\end{array}$ & NY-ESO-I & $\begin{array}{l}\text { CPG 7909/montanide ISA } 720 \text { with or without cyclophosphamide } \\
\text { in combination with either NY-ESO-I derived peptides or the } \\
\text { NY-ESO-I protein for NY-ESO-I expressing tumors }\end{array}$ & $\begin{array}{l}\text { NCT008I9806 } \\
\text { (A) }\end{array}$ \\
\hline Melanoma & NY-ESO-I & $\begin{array}{l}\text { Topical resiquimod and/or montanide ISA }{ }^{\circledast} 5 \text { I VG adjuvant } \\
\text { for NY-ESO-I protein vaccination }\end{array}$ & $\begin{array}{l}\text { NCT0082I652 } \\
\text { (A) }\end{array}$ \\
\hline Melanoma & MAGE-A3, NY-ESO-I & $\begin{array}{l}\text { Cytoreductive chemotherapy followed by infusion with MAGE-A3 } \\
\text { (A3A) or NY-ESO-I (c259) transduced autologous T cells }\end{array}$ & $\begin{array}{l}\text { NCT0I35040I } \\
\text { (R) }\end{array}$ \\
\hline Myeloma & MAGE-A3, NY-ESO-I & $\begin{array}{l}\text { Autologous T cells expressing a high affinity TCR specific for } \\
\text { MAGE-A3/6 or NY-ESO-I administered post ASCT }\end{array}$ & $\begin{array}{l}\text { NCT0I352286 } \\
\text { (A) }\end{array}$ \\
\hline $\begin{array}{l}\text { Hodgkin's or } \\
\text { non-Hodgkin's } \\
\text { lymphoma }\end{array}$ & NY-ESO-I, MAGE-A4 & $\begin{array}{l}\text { Autologous tumor-associated antigen-specific cytotoxic } \\
\text { T lymphocytes (primed against PRAME, SSX, MAGE-A4, } \\
\text { NY-ESO-I, and SURVIVIN pepmix) }\end{array}$ & $\begin{array}{l}\text { NCTOI } 333046 \\
(\mathrm{R})\end{array}$ \\
\hline Myeloma & MAGE-A3 & $\begin{array}{l}\text { GSK } 2 \text { I } 3223 \text { IA antigen-specific cancer immunotherapeutic } \\
\text { as adjuvant therapy in MAGE-A3 positive melanoma }\end{array}$ & $\begin{array}{l}\text { NCT00796445 } \\
\text { (A) }\end{array}$ \\
\hline
\end{tabular}

Abbreviations: A, active, not recruiting; ASCT, autologous stem cell transplantation; CT, cancer testis; R, recruiting; TCR, T cell receptor; TLR3, toll-like receptor 3; MAGE-AI, melanoma antigen family A, I; MAGE-A3, melanoma antigen family A, 3; NY-ESO-I, New York esophageal squamous cell carcinoma; DTPACE, dexamethasone, thalidomide, cisplatin, doxorubicin, cyclophosphamide and etoposide; CpG, cytosine-phosphate-guanine; IL-2: Interleukin-2; DEC-205: dendritic and epithelial cells, 205kDa; polyICLC, poly-inosinic-poly-cytidylic acid [Poly(l:C)] stabilized by lysine and carboxy methyl cellulose; MART, melanoma antigen recognized by T cells; recMAGE-A3, recombinant MAGE-A3; PRAME, preferentially expressed antigen in melanoma; SSX, synovial sarcoma $X$ chromosome. 
therapy, and immunotherapy have been combined in an attempt to improve clinical outcomes. This includes using chemotherapy and blockade of immune checkpoints, ${ }^{20,63,64}$ cancer vaccines and radiation therapy, ${ }^{65}$ cancer vaccines and chemotherapy, ${ }^{66,67}$ cancer vaccines and molecular-targeted agents, ${ }^{68}$ and molecular-targeted agents and blockade of immune checkpoints. ${ }^{69}$ Current available combinations of immunotherapy and molecular-targeted therapy for cancer treatment are summarized in a review by Vanneman and Dranoff. ${ }^{70}$ Depletion of Tregs in combination with a cancer vaccine is another approach. Tregs can be depleted by using anti-CD25 monoclonal antibodies ${ }^{71,72}$ and studies show that chemotherapy agents such as cyclophosphamide can deplete/ suppress Tregs. ${ }^{73,74}$ Among the different approaches available, we will focus our discussion on combining immunotherapy (using CT antigens) and chemotherapy, especially on the use of decitabine ([DAC] 5-aza-2'-deoxycytidine), a demethylating chemotherapeutic agent that epigenetically upregulates the expression of CT antigens, and review how CT antigens have been targeted in clinical trials.

The success of immunotherapy is largely dependent on the recognition of cancer cells expressing $\mathrm{CT}$ antigens by antigen-specific $\mathrm{T}$ cells, and this is dependent on antigen expression in the context of MHC class I and class II molecules. In cancer cells, hypermethylation of promoters leads to the downregulation of expression of CT antigens ${ }^{75}$ and $\mathrm{MHC}$ molecules, ${ }^{76}$ which are required for antigen presentation and recognition by antigen-specific cytotoxic $\mathrm{T}$ cells. Since not all tumors express CT antigens, one way to upregulate the expression of CT antigens and MHC molecules, and enhance tumor cell killing by antigenspecific cytotoxic $\mathrm{T}$ lymphocytes, would be to reverse hypermethylation by using demethylating agents. DAC is a potent inhibitor of DNA methylation, and the doses associated with the demethylating action of DAC are much lower than those required for cytotoxicity. ${ }^{77-80}$ Several groups have demonstrated that demethylating agents, such as DAC, upregulate the expression of MAGE-A1, MAGE-A3, and NY-ESO-1 in a number of tumor cell lines, ${ }^{81-84}$ potentially making these tumors more susceptible to MAGE-A1, MAGE-A3, and NY-ESO-1 mediated killing.

There have been several in vitro studies showing the effects of demethylating chemotherapy on the expression of $\mathrm{CT}$ antigens. One study demonstrated that the use of DAC could result in the restoration of MHC class I and MAGE antigens on melanoma cells. ${ }^{85}$ Another group demonstrated that the treatment of ovarian cancer cell lines with DAC resulted in the upregulation of MAGE-A1 and MAGE-A3 expression, as well as MHC class I molecules. ${ }^{81}$ Sigalotti et al treated 33 patients with AML or myelodysplastic syndrome (MDS) with DAC, and measured the expression of several CT antigens by RT-PCR. ${ }^{86}$ In 31 of 33 patients who had no $\mathrm{CT}$ antigen expression prior to treatment, de novo expression of MAGE-A1 and NY-ESO-1 was observed in all but one patient 15 days after treatment. Weber et al demonstrated that MAGE-A1 expression was upregulated on several malignant melanoma cell lines following exposure to DAC, ${ }^{83}$ and other studies have demonstrated that DAC can increase the expression of NY-ESO-1 on malignant glioma cell lines. ${ }^{87,88}$ Our group recently demonstrated that the majority of neuroblastoma cell lines had increased expression of MAGE-A1, MAGE-A3, and NY-ESO-1, on both a molecular and protein level, after 5 days exposure to DAC, and that this effect was associated with enhanced tumor cell killing by CT antigen specific CTL. ${ }^{89}$ Upregulation of CT antigens and enhanced killing of tumor cells following treatment with DAC by $\mathrm{CT}$ antigen specific $\mathrm{T}$ cells suggests that immunotherapy using CT antigens in combination with DAC can be a potential strategy to treat relapsed patients.

Our ongoing Phase I clinical trial combining DAC and a DC vaccine targeting MAGE-A1, MAGE-A3, and NY-ESO-1 for patients with relapsed neuroblastoma demonstrated a complete response in our first patient. The clinical outcome was correlated with a robust increase in the number of MAGE-A3 specific CD8 ${ }^{+}$and $\mathrm{CD}^{+} \mathrm{T}$ cells, and the patient remains disease free 1 year following his vaccination. ${ }^{90}$ This study indicates that a combination of demethylation-based chemotherapy followed by vaccine formulations containing CT antigens can elicit antigen-specific immune responses, potentially leading to an intensified antitumor effect.

Clinical trials are currently underway using genetically engineered NY-ESO-1 specific T cells for patients with synovial sarcoma, TCRs specific for MAGEA3/A6/B18 or NY-ESO-1/L antigen family member (LAGE) for patients with ovarian cancer, and TCRs specific for MAGE-A3 and NY-ESO-1 for patients with melanoma. Adoptive transfer of autologous $\mathrm{T}$ cells transduced with TCR directed against NY-ESO-1 has shown an objective clinical response in 4 of 6 patients with synovial cell sarcoma and in 5 of 11 patients with melanoma. ${ }^{91}$ This study demonstrated a partial response lasting 18 months in 1 of 6 patients with synovial cell sarcoma and a complete regression, that lasted over 12 months, in 2 of 11 patients with melanoma.

\section{Conclusion}

CT antigens are ideal targets for immunotherapy and success of CT antigen based immunotherapy is largely dependent on 
the recognition of cancer cells expressing CT antigens by antigen-specific T cells. Combination therapy that includes a combination of different immunotherapeutic modalities, or combination of immunotherapy with DAC and/or other chemotherapy/irradiation, or both could overcome the obstacles related to effective antitumor immunity. Such a combination therapy should primarily target upregulation of CT antigen expression and pro-apoptotic molecules on tumor cells, enhance the expression of MHC class I and class II molecules and costimulatory molecules on antigen presenting cells, and downregulate the expression of coinhibitory molecules on the surface of $\mathrm{T}$ cells. A combination therapy using agents to target all three types of cells could result in an antitumor immune response, and further studies addressing issues of cell dosage, timing, and necessary sequence of agents used could improve clinical outcomes.

\section{Disclosure}

The authors report no conflicts of interest in this work.

\section{References}

1. Yee C, Thompson JA, Byrd D, et al. Adoptive T cell therapy using antigen-specific CD8+ T cell clones for the treatment of patients with metastatic melanoma: in vivo persistence, migration, and antitumor effect of transferred T cells. Proc Natl Acad Sci U S A. 2002; 99(25):16168-16173.

2. Dudley ME, Wunderlich JR, Robbins PF, et al. Cancer regression and autoimmunity in patients after clonal repopulation with antitumor lymphocytes. Science. 2002;298(5594):850-854.

3. Yu JS, Liu G, Ying H, Yong WH, Black KL, Wheeler CJ. Vaccination with tumor lysate-pulsed dendritic cells elicits antigen-specific, cytotoxic T-cells in patients with malignant glioma. Cancer Res. 2004; 64(14):4973-4979.

4. Kono K, Takahashi A, Sugai H, et al. Dendritic cells pulsed with HER-2/ neu-derived peptides can induce specific T-cell responses in patients with gastric cancer. Clin Cancer Res. 2002;8(11):3394-3400.

5. Comito MA, Sun Q, Lucas KG. Immunotherapy for Epstein-Barr virusassociated tumors. Leuk Lymphoma. 2004;45(10):1981-1987.

6. Riddell SR, Greenberg PD. Principles for adoptive T cell therapy of human viral diseases. Annu Rev Immunol. 1995;13:545-586.

7. Walter EA, Greenberg PD, Gilbert MJ, et al. Reconstitution of cellular immunity against cytomegalovirus in recipients of allogeneic bone marrow by transfer of T-cell clones from the donor. $N$ Engl J Med. 1995;333(16):1038-1044.

8. Curran KJ, Pegram HJ, Brentjens RJ. Chimeric antigen receptors for $\mathrm{T}$ cell immunotherapy: current understanding and future directions. $J$ Gene Med. 2012;14(6):405-415.

9. Morgan RA, Dudley ME, Wunderlich JR, et al. Cancer regression in patients after transfer of genetically engineered lymphocytes. Science. 2006;314(5796):126-129.

10. Kerkar SP, Sanchez-Perez L, Yang S, et al. Genetic engineering of murine $\mathrm{CD} 8+$ and $\mathrm{CD} 4+\mathrm{T}$ cells for preclinical adoptive immunotherapy studies. J Immunother. 2011;34(4):343-352.

11. Choi BD, Cai M, Bigner DD, Mehta AI, Kuan CT, Sampson JH. Bispecific antibodies engage $\mathrm{T}$ cells for antitumor immunotherapy. Expert Opin Biol Ther. 2011;11(7):843-853.

12. Baitsch L, Baumgaertner P, Devêvre E, et al. Exhaustion of tumor-specific CD8(+) T cells in metastases from melanoma patients. J Clin Invest. 2011;121(6):2350-2360.
13. Norde WJ, Hobo W, van der Voort R, Dolstra H. Coinhibitory molecules in hematologic malignancies: targets for therapeutic intervention. Blood. 2012;120(4):728-736.

14. Gao J, Bernatchez C, Sharma P, Radvanyi LG, Hwu P. Advances in the development of cancer immunotherapies. Trends Immunol. 2013;34(2): 90-98.

15. Zhou Q, Munger ME, Highfill SL, et al. Program death-1 signaling and regulatory $\mathrm{T}$ cells collaborate to resist the function of adoptively transferred cytotoxic T lymphocytes in advanced acute myeloid leukemia. Blood. 2010;116(14):2484-2493.

16. Topalian SL, Hodi FS, Brahmer JR, et al. Safety, activity, and immune correlates of anti-PD-1 antibody in cancer. N Engl J Med. 2012; 366(26):2443-2454.

17. Brahmer JR, Tykodi SS, Chow LQ, et al. Safety and activity of anti-PD-L1 antibody in patients with advanced cancer. $N$ Engl $J$ Med. 2012;366(26):2455-2465.

18. Peggs KS, Quezada SA, Chambers CA, Korman AJ, Allison JP. Blockade of CTLA-4 on both effector and regulatory T cell compartments contributes to the antitumor activity of anti-CTLA-4 antibodies. $J$ Exp Med. 2009;206(8):1717-1725.

19. Weber J. Review: anti-CTLA-4 antibody ipilimumab: case studies of clinical response and immune-related adverse events. Oncologist. 2007;12(7):864-872.

20. Hodi FS, O'Day SJ, McDermott DF, et al. Improved survival with ipilimumab in patients with metastatic melanoma. $N$ Engl $J$ Med. 2010;363(8):711-723.

21. Margolin K, Ernstoff MS, Hamid O, et al. Ipilimumab in patients with melanoma and brain metastases: an open-label, phase 2 trial. Lancet Oncol. 2012;13(5):459-465.

22. Weber JS, Amin A, Minor D, et al. Safety and clinical activity of ipilimumab in melanoma patients with brain metastases: retrospective analysis of data from a phase 2 trial. Melanoma Res. 2011;21(6): 530-534.

23. Di Giacomo AM, Ascierto PA, Pilla L, et al. Ipilimumab and fotemustine in patients with advanced melanoma (NIBIT-M1): an open-label, single-arm phase 2 trial. Lancet Oncol. 2012;13(9):879-886.

24. Robert C, Thomas L, Bondarenko I, et al. Ipilimumab plus dacarbazine for previously untreated metastatic melanoma. N Engl J Med. 2011; 364(26):2517-2526.

25. Bolhassani A, Safaiyan S, Rafati S. Improvement of different vaccine delivery systems for cancer therapy. Mol Cancer. 2011;10:3.

26. Bendandi M, Gocke CD, Kobrin CB, et al. Complete molecular remissions induced by patient-specific vaccination plus granulocyte-monocyte colonystimulating factor against lymphoma. Nat Med. 1999;5(10):1171-1177.

27. Gnjatic S, Sawhney NB, Bhardwaj N. Toll-like receptor agonists: are they good adjuvants? Cancer J. 2010;16(4):382-391.

28. Palucka K, Banchereau J. Cancer immunotherapy via dendritic cells. Nat Rev Cancer. 2012;12(4):265-277.

29. Simpson AJ, Caballero OL, Jungbluth A, Chen YT, Old LJ. Cancer/ testis antigens, gametogenesis and cancer. Nat Rev Cancer. 2005;5(8): 615-625.

30. Chen YT, Ross DS, Chiu R, et al. Multiple cancer/testis antigens are preferentially expressed in hormone-receptor negative and high-grade breast cancers PLoS One. 2011;6(3):e17876.

31. Caballero OL, Chen YT. Cancer/testis (CT) antigens: potential targets for immunotherapy. Cancer Sci. 2009;100(11):2014-2021.

32. Restifo NP, Dudley ME, Rosenberg SA. Adoptive immunotherapy for cancer: harnessing the T cell response. Nat Rev Immunol. 2012; 12(4):269-281.

33. Scanlan MJ, Simpson AJ, Old LJ. The cancer/testis genes: review, standardization, and commentary. Cancer Immun. 2004;4:1.

34. Nicholaou T, Ebert L, Davis ID, et al. Directions in the immune targeting of cancer: lessons learned from the cancer-testis Ag NY-ESO-1. Immunol Cell Biol. 2006;84(3):303-317.

35. Zhang S, Zhou X, Yu H, Yu Y. Expression of tumor-specific antigen MAGE, GAGE and BAGE in ovarian cancer tissues and cell lines. $B M C$ Cancer. 2010;10:163. 
36. Wang XF, Cohen WM, Castelli FA, et al. Selective identification of HLA-DP4 binding T cell epitopes encoded by the MAGE-A gene family. Cancer Immunol Immunother. 2007;56(6):807-818.

37. Luiten R, Demotte N, Tine J, van der Bruggen P. A MAGE-A1 peptide presented to cytolytic T lymphocytes by both HLA-B35 and HLAA1 molecules. Tissue Antigens. 2000;56(1):77-81.

38. Luiten $\mathrm{R}$, van der Bruggen P. A MAGE-A1 peptide is recognized on HLA-B7 human tumors by cytolytic T lymphocytes. Tissue Antigens. 2000;55(2):149-152.

39. Pastorcic-Grgic M, Sarcevic B, Dosen D, Juretic A, Spagnoli GC, Grgic M. Prognostic value of MAGE-A and NY-ESO-1 expression in pharyngeal cancer. Head Neck. 2010;32(9):1178-1184.

40. Yoshida N, Abe H, Ohkuri T, et al. Expression of the MAGE-A4 and NY-ESO- 1 cancer-testis antigens and T cell infiltration in non-small cell lung carcinoma and their prognostic significance. Int J Oncol. 2006; 28(5):1089-1098.

41. Jungbluth AA, Antonescu CR, Busam KJ, et al. Monophasic and biphasic synovial sarcomas abundantly express cancer/testis antigen NY-ESO-1 but not MAGE-A1 or CT7. Int J Cancer. 2001;94(2):252-256.

42. Pollack SM, Jungbluth AA, Hoch BL, et al. NY-ESO-1 is a ubiquitous immunotherapeutic target antigen for patients with myxoid/round cell liposarcoma. Cancer. 2012;118(18):4564-4570.

43. Wölfl M, Jungbluth AA, Garrido F, et al. Expression of MHC class I, MHC class II, and cancer germline antigens in neuroblastoma. Cancer Immunol Immunother. 2005;54(4):400-406.

44. Rodolfo M, Luksch R, Stockert E, et al. Antigen-specific immunity in neuroblastoma patients: antibody and T-cell recognition of NY-ESO-1 tumor antigen. Cancer Res. 2003;63(20):6948-6955.

45. Barrow $\mathrm{C}$, Browning J, MacGregor $\mathrm{D}$, et al. Tumor antigen expression in melanoma varies according to antigen and stage. Clin Cancer Res. 2006;12(3 Pt 1):764-771.

46. Dhodapkar MV, Osman K, Teruya-Feldstein J, et al. Expression of cancer/testis (CT) antigens MAGE-A1, MAGE-A3, MAGE-A4, CT-7, and NY-ESO-1 in malignant gammopathies is heterogeneous and correlates with site, stage and risk status of disease. Cancer Immun. 2003;3:9.

47. Suyama T, Shiraishi T, Zeng Y, et al. Expression of cancer/testis antigens in prostate cancer is associated with disease progression. Prostate. 2010;70(16): 1778-1787.

48. Chaux P, Luiten R, Demotte N, et al. Identification of five MAGE-A1 epitopes recognized by cytolytic $\mathrm{T}$ lymphocytes obtained by in vitro stimulation with dendritic cells transduced with MAGE-A1. J Immunol. 1999;163(5):2928-2936.

49. Chianese-Bullock KA, Pressley J, Garbee C, et al. MAGE-A1-, MAGE-A10-, and gp100-derived peptides are immunogenic when combined with granulocyte-macrophage colony-stimulating factor and montanide ISA-51 adjuvant and administered as part of a multipeptide vaccine for melanoma. J Immunol. 2005;174(5):3080-3086.

50. Carrasco J, Van Pel A, Neyns B, et al. Vaccination of a melanoma patient with mature dendritic cells pulsed with MAGE-3 peptides triggers the activity of nonvaccine anti-tumor cells. J Immunol. 2008;180(5): 3585-3593.

51. Thurner B, Haendle I, Röder C, et al. Vaccination with mage-3A1 peptide-pulsed mature, monocyte-derived dendritic cells expands specific cytotoxic $\mathrm{T}$ cells and induces regression of some metastases in advanced stage IV melanoma. J Exp Med. 1999;190(11):1669-1678.

52. Connerotte T, Van Pel A, Godelaine D, et al. Functions of Anti-MAGE T-cells induced in melanoma patients under different vaccination modalities. Cancer Res. 2008;68(10):3931-3940.

53. Goodyear O, Agathanggelou A, Novitzky-Basso I, et al. Induction of a CD8+ T-cell response to the MAGE cancer testis antigen by combined treatment with azacitidine and sodium valproate in patients with acute myeloid leukemia and myelodysplasia. Blood. 2010;116(11): 1908-1918.

54. Nishikawa H, Maeda Y, Ishida T, et al. Cancer/testis antigens are novel targets of immunotherapy for adult T-cell leukemia/lymphoma. Blood. 2012;119(13):3097-3104.
55. Jäger E, Nagata $\mathrm{Y}$, Gnjatic $\mathrm{S}$, et al. Monitoring $\mathrm{CD} 8 \mathrm{~T}$ cell responses to NY-ESO-1: correlation of humoral and cellular immune responses. Proc Natl Acad Sci U S A. 2000;97(9):4760-4765.

56. Jäger E, Gnjatic S, Nagata Y, et al. Induction of primary NY-ESO-1 immunity: CD8+ T lymphocyte and antibody responses in peptidevaccinated patients with NY-ESO-1+ cancers. Proc Natl Acad Sci USA. 2000;97(22):12198-12203.

57. MacKensen A, Herbst B, Chen JL, et al. Phase I study in melanoma patients of a vaccine with peptide-pulsed dendritic cells generated in vitro from $\mathrm{CD} 34(+)$ hematopoietic progenitor cells. Int $J$ Cancer. 2000; 86(3):385-392.

58. Shackleton M, Davis ID, Hopkins W, et al. The impact of imiquimod, a Toll-like receptor-7 ligand (TLR7L), on the immunogenicity of melanoma peptide vaccination with adjuvant Flt3 ligand. Cancer Immun. 2004;4:9.

59. Chen Q, Jackson H, Shackleton M, et al. Characterization of antigen-specific CD8+ T lymphocyte responses in skin and peripheral blood following intradermal peptide vaccination. Cancer Immun. 2005;5:5.

60. Bender A, Karbach J, Neumann A, et al. LUD 00-009: phase 1study of intensive course immunization with NY-ESO-1 peptides in HLA-A2 positive patients with NY-ESO-1-expressing cancer. Cancer Immun. 2007;7:16.

61. Davis ID, Chen W, Jackson H, et al. Recombinant NY-ESO-1 protein with ISCOMATRIX adjuvant induces broad integrated antibody and CD4(+) and CD8(+) T cell responses in humans. Proc Natl Acad Sci US A. 2004;101(29):10697-10702.

62. Nicholaou T, Chen W, Davis ID, et al. Immunoediting and persistence of antigen-specific immunity in patients who have previously been vaccinated with NY-ESO-1 protein formulated in ISCOMATRIX ${ }^{\mathrm{TM}}$. Cancer Immunol Immunother. 2011;60(11):1625-1637.

63. Robert C, Thomas L, Bondarenko I, et al. Ipilimumab plus dacarbazine for previously untreated metastatic melanoma. $N$ Engl $J$ Med. 2011;364(26):2517-2526.

64. Rosenblatt J, Glotzbecker B, Mills H, et al. PD-1 blockade by CT-011, antiPD-1 antibody, enhances ex vivo T-cell responses to autologous dendritic cell/myeloma fusion vaccine. J Immunother. 2011;34(5): 409-418.

65. Gulley JL, Arlen PM, Bastian A, et al. Combining a recombinant cancer vaccine with standard definitive radiotherapy in patients with localized prostate cancer. Clin Cancer Res. 2005;11(9):3353-3362.

66. Arlen PM, Gulley JL, Parker C, et al. A randomized phase II study of concurrent docetaxel plus vaccine versus vaccine alone in metastatic androgen-independent prostate cancer. Clin Cancer Res. 2006;12(4):1260-1269.

67. Laheru D, Lutz E, Burke J, et al. Allogeneic granulocyte macrophage colony-stimulating factor-secreting tumor immunotherapy alone or in sequence with cyclophosphamide for metastatic pancreatic cancer: a pilot study of safety, feasibility, and immune activation. Clin Cancer Res. 2008;14(5):1455-1463.

68. Farsaci B, Higgins JP, Hodge JW. Consequence of dose scheduling of sunitinib on host immune response elements and vaccine combination therapy. Int J Cancer. 2012;130(8):1948-1959.

69. Stagg J, Loi S, Divisekera U, et al. Anti-ErbB-2 mAb therapy requires type I and II interferons and synergizes with anti-PD-1 or anti-CD137 mAb therapy. Proc Natl Acad Sci U S A. 2011;108(17):7142-7147.

70. Vanneman M, Dranoff G. Combining immunotherapy and targeted therapies in cancer treatment. Nat Rev Cancer. 2012;12(4):237-251.

71. Rech AJ, Vonderheide RH. Clinical use of anti-CD25 antibody daclizumab to enhance immune responses to tumor antigen vaccination by targeting regulatory T cells. Ann N Y Acad Sci. 2009;1174: 99-106.

72. Jacobs JF, Punt CJ, Lesterhuis WJ, et al. Dendritic cell vaccination in combination with anti-CD25 monoclonal antibody treatment: a phase I/II study in metastatic melanoma patients. Clin Cancer Res. 2010;16(20):5067-5078.

73. Zhao J, Cao Y, Lei Z, Yang Z, Zhang B, Huang B. Selective depletion of CD4+CD25+Foxp3+ regulatory $\mathrm{T}$ cells by low-dose cyclophosphamide is explained by reduced intracellular ATP levels. Cancer Res. 2010;70(12):4850-4858. 
74. van der Most RG, Currie AJ, Mahendran S, et al. Tumor eradication after cyclophosphamide depends on concurrent depletion of regulatory T cells: a role for cycling TNFR2-expressing effector-suppressor $\mathrm{T}$ cells in limiting effective chemotherapy. Cancer Immunol Immunother. 2009;58(8):1219-1228.

75. De Smet C, Lurquin C, Lethé B, et al. DNA methylation is the primary silencing mechanism for a set of germ line- and tumor-specific genes with a CpG-rich promoter. Mol Cell Biol. 1999;19(11):7327-7335.

76. Ye Q, Shen Y, Wang X, et al. Hypermethylation of HLA class I gene is associated with HLA class I down-regulation in human gastric cancer. Tissue Antigens. 2010;75(1):30-39.

77. Marks P, Rifkind RA, Richon VM, Breslow R, Miller T, Kelly WK Histone deacetylases and cancer: causes and therapies. Nat Rev Cancer. 2001;1(3):194-202.

78. Yang H, Hoshino K, Sanchez-Gonzalez B, Kantarjian H, Garcia-Manero G. Antileukemia activity of the combination of 5-aza2'-deoxycytidine with valproic acid. Leuk Res. 2005;29(7):739-748.

79. Garcia-Manero G, Gore SD. Future directions for the use of hypomethylating agents. Semin Hematol. 2005;42(3 Suppl 2): S50-S59.

80. Issa JP, Gharibyan V, Cortes J, et al. Phase II study of low-dose decitabine in patients with chronic myelogenous leukemia resistant to imatinib mesylate. J Clin Oncol. 2005;23(17):3948-3956.

81. Adair SJ, Hogan KT. Treatment of ovarian cancer cell lines with 5-aza-2'deoxycytidine upregulates the expression of cancer-testis antigens and class I major histocompatibility complex-encoded molecules. Cancer Immunol Immunother. 2009;58(4):589-601.

82. Schrump DS, Fischette MR, Nguyen DM, et al. Phase I study of decitabine-mediated gene expression in patients with cancers involving the lungs, esophagus, or pleura. Clin Cancer Res. 2006; 12(19):5777-5785

83. Weber J, Salgaller M, Samid D, et al. Expression of the MAGE-1 tumor antigen is up-regulated by the demethylating agent 5-aza-2' deoxycytidine. Cancer Res. 1994;54(7):1766-1771.
84. Almstedt M, Blagitko-Dorfs N, Duque-Afonso J, et al. The DNA demethylating agent 5-aza-2'-deoxycytidine induces expression of NY-ESO-1 and other cancer/testis antigens in myeloid leukemia cells. Leuk Res. 2010;34(7):899-905.

85. Serrano A, Tanzarella S, Lionello I, et al. Rexpression of HLA class I antigens and restoration of antigen-specific CTL response in melanoma cells following 5-aza-2'-deoxycytidine treatment. Int J Cancer. 2001;94(2):243-251.

86. Sigalotti L, Altomonte M, Colizzi F, et al. 5-Aza-2'-deoxycytidine (decitabine) treatment of hematopoietic malignancies: a multimechanism therapeutic approach? Blood. 2003;101(11):4644-4646.

87. Oi S, Natsume A, Ito M, et al. Synergistic induction of NY-ESO-1 antigen expression by a novel histone deacetylase inhibitor, valproic acid, with 5-aza-2'-deoxycytidine in glioma cells. J Neurooncol. 2009;92(1):15-22.

88. Natsume A, Wakabayashi T, Tsujimura K, et al. The DNA demethylating agent 5-aza-2'-deoxycytidine activates NY-ESO-1 antigenicity in orthotopic human glioma. Int J Cancer. 2008;122(11):2542-2553.

89. Bao L, Dunham K, Lucas K. MAGE-A1, MAGE-A3, and NY-ESO-1 can be upregulated on neuroblastoma cells to facilitate cytotoxic T lymphocyte-mediated tumor cell killing. Cancer Immunol Immunother. 2011;60(9):1299-1307.

90. Krishnadas DK, Shapiro T, Lucas K. Complete remission following decitabine/dendritic cell vaccine for relapsed neuroblastoma. Pediatrics. 2013;131(1):e336-e341.

91. Robbins PF, Morgan RA, Feldman SA, et al. Tumor regression in patients with metastatic synovial cell sarcoma and melanoma using genetically engineered lymphocytes reactive with NY-ESO-1. J Clin Oncol. 2011;29(7):917-9290
ImmunoTargets and Therapy

\section{Publish your work in this journal}

ImmunoTargets and Therapy is an international, peer-reviewed open access journal focusing on the immunological basis of diseases, potential targets for immune based therapy and treatment protocols employed to improve patient management. Basic immunology and physiology of the immune system in health, and disease will be also covered. In addition, the journal will focus on the impact of manage-

\section{Dovepress}

ment programs and new therapeutic agents and protocols on patient perspectives such as quality of life, adherence and satisfaction. The manuscript management system is completely online and includes a very quick and fair peer-review system, which is all easy to use. Visit http://www.dovepress.com/testimonials.php to read real quotes from published authors. 